\section{SOI: $1.1 /$ TAS DOI: $10.15863 /$ TAS International Scientific Journal Theoretical \& Applied Science}

p-ISSN: 2308-4944 (print) e-ISSN: 2409-0085 (online)

Year: $2016 \quad$ Issue: 6 Volume: 38

Published: $30.06 .2016 \quad \underline{\text { http://T-Science.org }}$
Yumeng Zhang

College of Economics \& Management, Anhui Agricultural University, Hefei Anhui China 230036 604943394@qq.com

Yuneng DU

College of Economics \& Management, Anhui Agricultural University, Hefei Anhui China 230036

SECTION 31. Economic research, finance, innovation, risk management.

\title{
STUDY ON THE CONSUMPTION LEVEL OF RURAL RESIDENTS IN CHINA
}

\begin{abstract}
Since the reform and opening-up, great changes have taken place in China and the public standards of living in China's rural areas have improved dramatically. This paper aimed to figures out what factors that make difference on the consumption level of rural residents in China. Three affecting factors were chosen as explanatory variables: Rural Consumer Price Index, per capita disposable income of rural residents, Engel Coefficient of rural households. Then this paper made use of EVIEWS 3.1 for parameter estimation, model test and model modification. Final model estimation results shows that when rural residents' per capita disposable income increases by 1 yuan, rural residents' consumption level will increase by 0.7277 yuan; when the Engel Coefficient of rural households rise by 1\%, rural residents' consumption level will decrease by 6.5794 yuan. Some suggestions were also put forward at the end.

Key words: Consumption Level, Affecting factors, Rural Residents, China.

Language: English

Citation: Zhang Y, Du Y (2016) STUDY ON THE CONSUMPTION LEVEL OF RURAL RESIDENTS IN CHINA. ISJ Theoretical \& Applied Science, 06 (38): 101-105.

Soi: http://s-o-i.org/1.1/TAS-06-38-20 Doi: crossef http://dx.doi.org/10.15863/TAS.2016.06.38.20
\end{abstract}

\section{Introduction}

Recent years have witnessed Chinese rapid development in various aspects. Taking its rural residents' consumption level for example, China's residential consumption level is 184 yuan in 2001 and it increases to 10919 yuan in 2010.

Residential consumption level, as its definition says, refers to the attainable level to meet people's demand of surviving, developing and enjoying in the process of the consumption of material goods and services. Residential consumption level is mainly affected by the economy [1]. Gross domestic product (GDP) is an overall economic indicator often used to measure a country's total revenue. When the economy is in its expansion period, the income is stable, the GDP is high, residential spending in consumption is more, so the consumption level is higher; On the contrary, when the economy is in its contraction period, the income drops, the GDP is low, residential spending in consumption is less, so the consumption level also drops.

As the economy grows, Chinese rural areas are also experiencing dramatic change. The living standards of rural residents have generally improved and their consumption level also changes a lot. From 2002 to 2007, per capita consumption expenditure of rural residents increases from 1834 yuan to 3224 yuan, an increase of $75.8 \%$ and an average annual growth of $11.9 \%$.In real terms, the average annual real growth rate is $8.0 \%$.In 2007, rural residential spending per person respectively increases by $63.7 \%$, $84.2 \%, 91.2 \%$ and $63.7 \%$ than that in 2002 in the aspects of food, clothing, housing and household appliances; the consumption level in traffic communication, cultural and educational entertainment, health care and other aspects respectively increase by 1.6 times, respectively, $45.3 \%, 1.0$ times and $28.7 \%$ than that in 2002.From 2002 to 2007, the Engel Coefficient of rural residents' consumption shows a more obvious decline year by year, felling from $46.25 \%$ in 2002 to $43.08 \%$ in 2007.The Engel coefficient is an international general indicators reflecting the state of the rich and the poor. According to the standard of the United Nations Food and Agriculture Organization (FAO), when the Engel Coefficient is more than $60 \%$, it is for the poor; from $50 \%$ to $59 \%$, it is for the sufficiency of food and clothing; from $40 \%$ to $49 \%$, it is for the well-off; from $30 \%$ to $39 \%$, it is for the rich and below $30 \%$ it is for the richest. In accordance with the above standard, Chinese rural residents' consumption level is in the stage of well- 


\begin{tabular}{|c|c|c|c|c|c|c|}
\hline Impact Factor: & $\begin{array}{l}\text { ISRA (India) } \\
\text { ISI (Dubai, UAE } \\
\text { GIF (Australia) } \\
\text { JIF }\end{array}$ & $\begin{array}{r}=1.344 \\
=0.829 \\
=0.564 \\
=1.500\end{array}$ & $\begin{array}{l}\text { SIS (USA) } \\
\text { PИНЦ (Russia) } \\
\text { ESJI (KZ) } \\
\text { SJIF (Morocco) }\end{array}$ & $\begin{array}{l}=0.912 \\
=0.234 \\
=1.042 \\
=\mathbf{2 . 0 3 1}\end{array}$ & $\begin{array}{l}\text { ICV (Poland) } \\
\text { PIF (India) } \\
\text { IBI (India) }\end{array}$ & $\begin{array}{l}=6.630 \\
=1.940 \\
=4.260\end{array}$ \\
\hline
\end{tabular}

off, and the consumption level is still increasing year by year.

Consumption have always been the focus and hot of economics research, There are many domestic experts and scholars studying the problem from the aspects of income, consumption expenditure, prices, gap between the rich and the poor, regional industry and so on[2] [3] [4]. In this paper, in order to know more about the consumption level and maintain sustainable economic growth in China's rural areas, affecting factors were studied with a large number of empirical data of the consumption level of rural residents in China.

\section{Materials}

In this paper, rural residents' consumption level was seen as dependent variable, represented by $\mathrm{Y}$, and three affecting factors were chosen for the research: Rural Consumer Price Index, per capita disposable income of rural residents, Engel Coefficient of rural households.

According to relevant economics theory, income is main factor influencing the consumer. For example, it is told in Keynes's absolute income theory that consumption is a function of people's income level and its formula is as follows: $\mathrm{C}=\alpha+$ $\beta Y_{t}$. In this formula, $C$ is for current consumption, $\alpha$ is for autonomous consumption, $\beta$ is for marginal propensity to consume, $\mathrm{Y}_{\mathrm{t}}$ is for immediate income, and $\beta Y_{t}$ is for induced consumption. That is to say that consumption is the sum of autonomous consumption and induced consumption, and consumption mainly depending on immediate income will increase with the increase of income [5]. On the other hand, in the relative income hypothesis proposed by James Stemble Duesenberry, consumption is up to income distribution and the highest income level of consumers in the history. Duesenberry put forward that consumption does not depend on current absolute income level but on relative income level, including two aspects: one is the income level relative to other people's income level, referring to that consumers' consumption behavior will be affected by each other, generally called "demonstration effect" or "bandwagon effect"; the other is the income level relative to consumers' own historical consumption level, referring to that because of consumers' consumption habit, their consumption will not necessarily reduce immediately when their income reduces, generally called "habit effect" [6]. Therefore, considering a decisive role the income plays in consumers' consumption level, in this paper, per capita disposable income of rural residents was used as one of explanatory variables, represented by $\mathrm{X}_{2}$.

Another affecting factor considered is price. Price is the expression form in currency of commodity value. Commodity prices directly have something to do with the vital interests of buyers and sellers, and also directly affect consumers' purchase intention of certain goods as well as their purchase quantity. Commodity price is the most sensitive factor of consumers' purchase psychology. Price as an objective factor has impact on consumers' purchasing psychology, thus further influences consumers' buying behavior [7]. As the consumer price index is used to reflect changes in the price level of household goods and services, so in this paper, Rural Consumer Price Index was used as the second explanatory variable, represented by $\mathrm{X}_{1}$.

The third explanatory variable in this paper is Engel Coefficient of rural households, represented by $\mathrm{X}_{3}$.Engel Coefficient is household expenses for food as a percentage of total expenditure for a period of time. Usually, the lower the coefficient is, the higher people's consumption level is, and the higher the coefficient is, the lower people's consumption level is $[8]$.

This paper collected the related data of rural residents' consumption level from 1991-2010 in China, as is shown in the following table. All data is from China Statistical Yearbook.

Related data of rural residents' consumption level from 1991-2010 in China.

Table 1

\begin{tabular}{|c|c|c|c|c|}
\hline year & $\mathrm{Y}$ & $\mathrm{X}_{1}$ & $\mathrm{X}_{2}$ & $\mathrm{X}_{3}$ \\
\hline 1991 & 602 & 102.3 & 708.6 & 57.6 \\
\hline 1992 & 688 & 104.7 & 784.0 & 57.6 \\
\hline 1993 & 805 & 113.7 & 921.6 & 58.1 \\
\hline 1994 & 1038 & 123.4 & 1221.0 & 58.9 \\
\hline 1995 & 1313 & 117.5 & 1577.7 & 58.6 \\
\hline 1996 & 1626 & 107.9 & 1926.1 & 56.3 \\
\hline 1997 & 1722 & 102.5 & 2090.1 & 55.1 \\
\hline 1998 & 1730 & 99.0 & 2162.0 & 53.4 \\
\hline
\end{tabular}




\begin{tabular}{|c|c|c|c|c|c|c|}
\hline Impact Factor: & $\begin{array}{l}\text { ISRA (India) } \\
\text { ISI (Dubai, UAE } \\
\text { GIF (Australia) } \\
\text { JIF }\end{array}$ & $\begin{array}{l}=1.344 \\
=0.829 \\
=0.564 \\
=1.500\end{array}$ & $\begin{array}{l}\text { SIS (USA) } \\
\text { PИНЦ (Russia) } \\
\text { ESJI (KZ) } \\
\text { SJIF (Morocco) }\end{array}$ & $\begin{array}{l}=0.912 \\
=0.234 \\
=1.042 \\
=2.031\end{array}$ & $\begin{array}{l}\text { ICV (Poland) } \\
\text { PIF (India) } \\
\text { IBI (India) }\end{array}$ & $\begin{array}{l}=6.630 \\
=1.940 \\
=4.260\end{array}$ \\
\hline
\end{tabular}

\begin{tabular}{|l|c|c|c|c|}
\hline 1999 & 1766 & 98.5 & 2210.3 & 52.6 \\
\hline 2000 & 1860 & 99.9 & 2253.4 & 49.1 \\
\hline 2001 & 1969 & 100.8 & 2366.4 & 47.7 \\
\hline 2002 & 2062 & 99.6 & 2475.6 & 46.2 \\
\hline 2003 & 2103 & 101.6 & 2622.2 & 45.6 \\
\hline 2004 & 2319 & 104.8 & 2936.4 & 47.2 \\
\hline 2005 & 2579 & 102.2 & 3254.9 & 45.5 \\
\hline 2006 & 2868 & 101.5 & 3587.0 & 43.0 \\
\hline 2007 & 3293 & 105.4 & 4140.4 & 43.1 \\
\hline 2008 & 3795 & 106.5 & 4760.6 & 43.7 \\
\hline 2009 & 4021 & 99.7 & 5153.2 & 41.0 \\
\hline 2010 & 4455 & 103.6 & 5919.0 & 41.1 \\
\hline
\end{tabular}

\section{Methods}

Based on the above materials,model was preliminarily built as $\mathrm{Y}=\mathrm{C}+\mathrm{C}_{1} * \mathrm{X}_{1}+\mathrm{C}_{2} * \mathrm{X}_{2}+$ $\mathrm{C}_{3} * \mathrm{X}_{3}+\varepsilon$.After getting the estimators of model parameter, an econometric model had been preliminarily established, but it remained to be seen whether the model can objectively reveal the relationship between factors in the economic phenomena. Therefore, the next step was model test, including economic significance test, statistical tests, econometric test and model prediction test.this paper used EVIEWS 3.1 for parameter estimation, model test and model modification.

Model modification mainly used the method of stepwise regression in this paper.The basic idea of stepwise regression is to introduce variable models into the model one by one. After the introduction of one variable, the model should be tested with $\mathrm{F}$ test, and elected variables should be tested with T test one by one. If the previous explanatory variable is no longer significant due to the introduction of the next explanatory variable, the previous one should be deleted from the model, in this way ensuring that regression equation contains only significant variables before introducing a new variable. This is an iterative process to ensure to get optimum explanation variables, until there are no significant explanatory variables being selected into the regression equation and no significant explanatory variables being removed from the regression equation[9].

Based on the above ideas, stepwise regression can be used to filter and eliminate variables that result in multicollinearity. Specific steps are as follows: firstly doing simple regression between explained variables and each explanatory variable, then on the basis of the corresponding regression equation of the explanatory variable which contributes most to explained variable, introducing rest variables one by one. Through stepwise regression, it makes sure that final equation reserves important variables and has no serious multicollinearity[10].

\section{Results}

4.1 parameter estimation

Through EVIEWS 3.1, the model was preliminarily estimated, as follow:

$$
\begin{aligned}
& \hat{Y}_{i}=469.3652+1.7884 \mathrm{X}_{1}+0.7215 \mathrm{X}_{2}-8.8007 \mathrm{X}_{3} \\
& \begin{array}{lllll}
S . \hat{E}(\beta) & (250.8966) & (2.2105) & (0.01904) & (4.8007) \\
t & (1.8708) & (0.6090) & (37.8879) & (-1.83332) \\
R^{2}=0.9983 ; & \bar{R}^{2}=0.9980 ; \mathrm{DW}=1.0545 ; \mathrm{F}=3194.701 ; \hat{\sigma}=48.4463 ; \mathrm{p}(\mathrm{f})=0.00000
\end{array}
\end{aligned}
$$

4.2 model test

With regard to the goodness of fit test and significance testing, the significance level was set to be 0.05 in this paper. The value of $R^{2}$ is equal to 0.9980 , closing to 1 , showing that model has a high goodness of fit; $\mathrm{F}=3194.401\rangle F_{\alpha}(3-1,20-3)=$ 3.59 , showing that the model has a significant linear relationship, or Rural Consumer Price Index, per capita disposable income of rural residents, Engel Coefficient of rural households have a jointly significant influence to the consumption level; the T value of Rural Consumer Price Index is 0.6090,less than the value of $t_{\alpha / 2}(20-3)$ that is equal to 2.110,showing that Rural Consumer Price Index does not significantly affect the consumption level; the $\mathrm{T}$ 
value of per capita disposable income is 37.8879 ,more than the value of $t_{\alpha / 2}(20-3)$ that is equal to 2.110 ,showing that per capita disposable income has a significant influence to the consumption level; the $\mathrm{T}$ value of Engel Coefficient is 1.8333 ,lower than the value of $t_{\alpha / 2}(20-3)$ that is equal to 2.110,showing that Engel Coefficient has no significant influence to the consumption level.

In terms of economic sense, assuming that other explanation variables remains unchanged, the model shows that when Rural Consumer Price Index rises by $1 \%$, rural residents' consumption level will increase by 1.7884 yuan; when rural residents' per capita disposable income rises by $1 \%$, rural residents' consumption level will increases by 0.7215 yuan; when Engel Coefficient rises by $1 \%$, rural residents' consumption level will decrease by 8.007 yuan.

Considering there are three explanation variables in the model, test for multi-collinearity is necessary to find out if correlation exists among explanation variables. Multicollinearity will lead to the distortion of parameter estimation. Through related-coefficient test, it shows that explanatory variables are related to rural residents' consumption level, and there exists pairwise correlation among variables, so next step was to modify the model.

\section{3 model modification}

According to the principle of stepwise regression, Rural residents' per capita disposable income should be the main factor that influence rural residents' consumption level, and the correlation coefficient test also shows that rural residents' per capita disposable income has the strongest relevance with rural residents' consumption level, so, $\mathrm{Y}=\mathrm{C}+$ $\mathrm{C}_{2} * \mathrm{X}_{2}+\varepsilon$ was set as basic model.

After introducing other rest explanatory variables one by one, final model of rural residents' consumption level was determined as follow:

$$
\begin{aligned}
& \mathrm{Y}=529.0466+0.7277 \mathrm{X}_{2}-6.5794 \mathrm{X}_{3} \\
& \begin{array}{lll}
(237.3581) & (0.0173) \quad(3.8978)
\end{array} \\
& \mathrm{T}=(2.2289) \quad(42.1161) \quad(-1.6880) \\
& \mathrm{R}^{2}=0.9982 ; \quad \bar{R}^{2}=0.9981 ; \mathrm{F}=4891.113 ; \mathrm{S} . \mathrm{E}=48.1674 ; \mathrm{D} . \mathrm{W}=1.0281 ; \mathrm{p}(\mathrm{f})=0.0000
\end{aligned}
$$

The value of $R^{2}$ is equal to 0.9981 , closing to 1 , showing that model has a high goodness of fit; the value of $\mathrm{F}$ is equal to 3194.401 , more than the critical value that is equal to 4.41 , showing that the model has a significant linear relationship, or per capita disposable income of rural residents and Engel Coefficient of rural households have a jointly significant influence to the consumption level. On the other hand, its $\mathrm{P}$ value is 0.000000 ,obviously less than the significance level of 0.05 , showing that each variable has a significant influence on rural residents' consumption level Y and linear relation is obvious in the model; the $\mathrm{T}$ value of per capita disposable income is 42.1161 , more than the critical value of 2 , showing that per capita disposable income has a significant influence on the consumption level; the $\mathrm{T}$ value of Engel Coefficient is lower than 2,showing that Engel Coefficient has no significant influence to the consumption level.

In terms of economic sense, assuming that other explanation variables remains unchanged, the model shows that when Rural Consumer Price Index rises by $1 \%$, rural residents' consumption level will increase by 1.7884 yuan; when rural residents' per capita disposable income rises by $1 \%$, rural residents' consumption level will increases by 0.7277 yuan; when Engel Coefficient rises by $1 \%$, rural residents' consumption level will by 6.5794 yuan.

\section{Discussions and Conclusions}

This paper was to study what factors that makes difference to the consumption level of rural residents in China. According to some Economic theories, three affecting factors were chosen as explanatory variables: Rural Consumer Price Index, per capita disposable income of rural residents, Engel Coefficient of rural households. Then this paper used EVIEWS 3.1 for parameter estimation, model test and model modification. Model test included economic significance test, statistical tests, econometric test and model prediction test in this paper, and model modification mainly used the method of stepwise regression. After introducing explanatory variables one by one, Rural Consumer Price Index was deleted from the model, and final model of rural residents' consumption level was determined as follow: $\mathrm{Y}=529.0466+0.7277 \mathrm{X} 2$ 6.5794X3. Final model estimation results shows that when rural residents' per capita disposable income increases by 1 yuan, rural residents' consumption level will increase by 0.7277 yuan; when the Engel Coefficient of rural households rise by $1 \%$, rural residents' consumption level will decrease by 6.5794 yuan.

Based on these conclusions, this paper would like to put forward some suggestions to improve 


\begin{tabular}{|c|c|c|c|c|c|c|}
\hline Impact Factor: & $\begin{array}{l}\text { ISRA (India) } \\
\text { ISI (Dubai, UAE } \\
\text { GIF (Australia) } \\
\text { JIF }\end{array}$ & $\begin{array}{r}=1.344 \\
=0.829 \\
=0.564 \\
=1.500\end{array}$ & $\begin{array}{l}\text { SIS (USA) } \\
\text { PИНЦ (Russia) } \\
\text { ESJI (KZ) } \\
\text { SJIF (Morocco) }\end{array}$ & $\begin{array}{l}=0.912 \\
=0.234 \\
=1.042 \\
=\mathbf{2 . 0 3 1}\end{array}$ & $\begin{array}{l}\text { ICV (Poland) } \\
\text { PIF (India) } \\
\text { IBI (India) }\end{array}$ & $\begin{array}{l}=6.630 \\
=1.940 \\
=4.260\end{array}$ \\
\hline
\end{tabular}

rural residents' consumption level from following aspects.

On the one hand, the core of the issues concerning agriculture, countryside and farmers is how to increase farmers' income. Only on the premise that farmers' income increases can standard of peasants' lives fundamentally improve, as well as their consumption level. As agricultural income is still the main part of farmers' income, especially in the central and western regions, agricultural income is still the basis of farmers' income growth [11]. In order to realize steady growth of farmers' income, it is necessary to perfect the support and protection system offered by government for agriculture. For example, government can make more efforts to deepen rural reforms, perfect policies to aid agriculture and benefit farmers, improve farm produce price forming mechanism and agricultural subsidies and strengthen the financial service. Also, it is important to unswervingly speed up the transformation of the mode of agricultural development to realize agriculture modernization. Of course, increasing farmers' income is not just limited to consider increasing, but also reducing farmers' spending like expenditures for education, medical treatment and so on, which is also a kind of effective way to increase income. Therefore, government should vigorously develop rural education, health and other social undertakings.

On the other hand, improving rural residents' consumption structure is also an aspect to improve rural residents' consumption level [12]. To achieve this, Firstly, strengthen rural consumer education and change rural residents' consumption concept .Rural residents' consumption concept is relatively backward, which is an important factor that affects the upgrading of their consumption structure.so, it is necessary to through the propaganda education change rural residents' consumption ideas and cultivate their good habits of consumption. Secondly, expand the consumer area. Short power supply, inconvenient traffic, poor commodity circulation and bad market order have always been preventing rural residents' consumption structure from upgrading. Government should further increase investment in agricultural and rural infrastructure, improving the infrastructure of rural production and living, especially in the areas of merchandise trade, culture, sports, travel, broadband network and other infrastructure constructions, to promote cultural consumption, tourism consumption and Old - Age consumption.

\section{References:}

1. Chen G, Luo C, School B, University BN, Economics SO, University NN (2015) Analysis on factors to impact proportion of china's urban and rural residents' per capita income in gdp- based on perspective of time and region. Journal of Beijing Technology \& Business University.

2. Fei GE, Jing H (2009) Comparative analysis on the effects of income structure on consumption level of rural residents in eastern and western china_a case study on jiangsu and xinjiang provinces. Asian Journal of Agricultural Research, 1(8), 1-5.

3. Jing H (2009) Study on the relations between income structure change and consumption of rural residents in china. Asian Journal of Agricultural Research, 1(8), 11-14, 48.

4. Yuan YZ (2013) Empirical research on the prediction of consumption level of rural residents in china. Jiangsu Commercial Forum.

5. Alimi RS (2013) Keynes' absolute income hypothesis and kuznets paradox. Mpra Paper.

6. Alvarez-Cuadrado F, Long NV (2011) The relative income hypothesis. Journal of
Economic Dynamics \& Control, 35(9), 14891501.

7. Yang W (2009) Analysis on the impact of agricultural product price change on the countryside inhabitant cpi and the farmer consumption level. Journal of Regional Financial Research.

8. Chuan-Yan AN (2014) Some thoughts on engel's coefficient,the tourism engel's coefficient. Journal of Nanyang Normal University.

9. Wilkinson L (1978) Tests of significance in stepwise regression. Psychological Bulletin, 86(86), 168-174

10. Sun NZ, Yang SL, Yeh WG (1998) A proposed stepwise regression method for model structure identification. Water Resources Research, 34(34), 2561-2572.

11. Yi H (2011) Obstacles to rural residents' consumption in china and the countermeasures. Asian Journal of Agricultural Research, 03(6).

12. Zhao WY (2000) Changes in the consumption structure of rural residents in china. Chinese Rural Economy(9), 13-17. 